of purely volcanic ash-mostly of a clearly sedimentary originreposing upon thin seams of coal and shale, and enclosing a considerable number of fossil plants in a beautiful state of preservation.

Up to the present time, I have accurately surveyed a distance of only about 400 feet along the shore; and within this comparatively narrow area are found no less than ten distinct beds of trappean ash.

Trunks of trees, 18 to 24 inches in diameter, and 2 to 3 feet in height, standing erect upon the original beds of thin coal and shale upon which they grew, and covered by layers of ash 2 to 3 feet in thickness, are found regularly dispersed over the area; while the ash overlying them, in which they are embedded, contains numerous branches, from 4 inches in diameter down to the minutest dimensions, some of the impressions displaying an almost feathery foliage, as though suddenly covered up before the vegetation had had time to decay or become water-worn. The larger branches remain perfectly round, and show the pith in an admirable state of preservation; and the cellular tissue, filled up with mineral matter, is plainly visible to the naked eye.

The specimens of the smaller branches thus far obtained indicate the genera Lepidodendron and Halonia; but I have had no opportunity as yet of having them examined microscopically. As far as can be determined by a simple botanical glass, the structure is very similar to the sections of Lepidodendron, \&c. figured and described by Mr. Binney in the 'Quarterly Journal of the Geological Society' for January 1862.

The whole of the beds belong to the Lower Carboniferous series underlying the Producta-limestones, and there are indications of beds of a similar character both above and below those described. The mineralogical character of the beds is highly interesting, and has been examined jointly with me by my friend and colleague, Mr. John Young, of the Hunterian Museum. A joint paper on the subject will be laid by us before the Geological Society of Glasgow at an early date: meanwhile, if you think the announcement of the discovery of fossil plants under the circumstances stated may be interesting to your geological readers generally, the above details are quite at your service, and I remain, dear Sir,

Yours very truly, E. A. WüNsCH,

Aniersontan Untyersity Buildings, $\quad$ V. P. Geol. Soc., Glasgow.

GLASGOW: Sept. 9, 1865.

\title{
NOTE ON THE ANALYSIS OF A DEPOSIT CONTAINING
} SULPHATE OF BARYTA.

To the Editor of the Geologrcal Magazine.

Srr,-At a late meeting of the Glasgow Geological Society, Mr. Thomson exhibited a compact mass which had been deposited in a pipe, apparently a square wooden one, used for conveying water from Harton Pit, near South Shields, which is about 200 fathoms deep.

The deposit is a hard, compact, light-brown mass, with darkbrown streaks running through it. The portion shown was about 
1 foot long, 5 inches square, and 2 inches thick, and appears to have almost entirely filled up the pipe, retaining its square form throughout: the whole was deposited in the short space of from six to nine months.

The chemical composition, which is rather remarkable, is as follows :-

$$
\text { (Sp. gr. at } 15 \cdot 5 \text { C., } 3 \cdot 646 . \text { ) }
$$

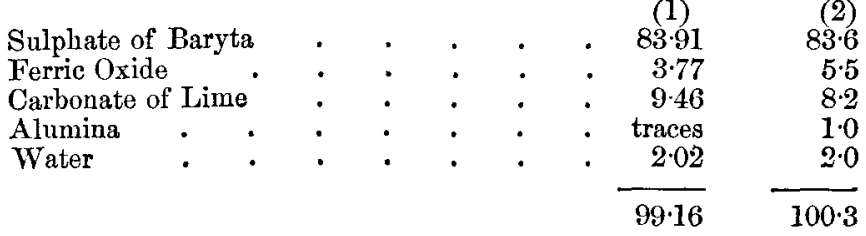

No. 1 was from the centre of the deposit, No. 2 from the outside. This analysis was made by a friend.

The only reference which I have been able to find with regard to the occurrence of sulphate of baryta in coal-pits is in a paper by Messrs. R. C. Clapham and T. Daglish, read before the British Association at Newcastle in 1863. It is there stated that Mr. Foster had found quite a large mass: Dr. Richardson also had observed it in the waters of Walker Colliery.-Yours truly,

Grasgow.

J. WALlace Yodng.

DENUDATION, UNCONFORMABILITY, AND THE VALE OF CLWYD.

To the Editor of the Geological Magazine.

Sir,-Geological notions, like all others, occasionally swing pendulum-like from one extreme to the other. The old controversy between the respective importance of Fire and Water has not ceased; though, judging from the number of important results which are now attributed to its denuding power, Water is evidently in the ascendant. Believing myself that these results are rather over-estimated, I am induced to offer to your readers the following remarks.

A gap in the order of strata-as, for example, Carboniferous Limestone resting upon Lower Silurian rocks, or the Trias, as in the Vale of Clwyd, supposed to rest upon the Carboniferous Limestone-does not necessarily imply the denudation of the strata missing from between them; for it is possible to conceive that towards the close of the deposition (or indeed at any period during its deposition) of any group of strata, the deposit might, in any portion, or the whole of it, be raised above the sea-level, and so remain, while newer deposits were being formed around it; and so a hiatus in the order of the strata would be caused, which would be greater or less in proportion to the time the relative positions of sea and land remained unchanged.

Thus, suppose in any particular district the sea-bottom to have been elevated towards the close of the Lower Silurian period, and to have remained above the sea-level until the Old Red Sandstone was deposited, and then be again submerged, we should in that 